\title{
STUDI ANALISIS TENTANG SISTEM PERWALIAN DALAM PERKAWINAN ADA DIDESA MBUJU KECAMATAN KILO KABUPATEN DOMPU TAHUN 2012/2013
}

\author{
WAYAN RESMINI, MH. WAWANKURNIAWAN \\ (Dosen PNS Dpk. Kopertis Wilayah VIII)
}

\begin{tabular}{l} 
INFO ARTIKEL \\
\hline Riwayat Artikel: \\
Diterima: $10-09-2016$ \\
Disetujui: $30-09-2016$ \\
\end{tabular}

\section{Kata Kunci:}

Perwalian, Perkawinan, HukumAdat.

\begin{abstract}
ABSTRAK
Abstrak: Wali nikah memiliki kedudukan yang sangat penting dalam perkawinan, dan tidak dapat di pungkiri karena walinikah merupakan unsur yang sangat menentukan perkawinan itu menjadi syah atau tidak syahnya suatu perkawinan.Di Desa Mbuju dalam melaksanakan perkawinan misalnya, terlihat berbagai gejala yang sangat beragam, padahal ada perarturan yang normatif. Dengan demikian tidaklah cukup bila masalah beragam itu ditonton begitu saja melainkan diperlukan adanya keterlibatan dan pengabdian pihak-pihak intelektual sehingga terbuka peluang sosial yang tepat untuk menyelamatkan kehidupan masyarakat.Masalah dalam penelitian ini adalah "Bagaimanakah sistem perwaliandalam perkawinan Adat di Desa Mbuju Kecematan Kilo Kabupaten Dompudan Kendala apa saja yang dihadapi wali nikah dalam perkawinan Adat di Desa Mbuju Kecematan Kilo Kabupaten Dompu".Dengan demikian penelitian ini bertujuan untuk menguji secara empirik tentang bagaimana kedudukan wali nikah dalam perkawinan Adat di Desa Mbuju Kecematan Kilo Kabupaten Dompu.

Penelitian ini mengunakan metode diskripsi analisis kualitatif yang mengkaji permasalahan secara analitis, sistimatis, ilmiah dan logis dengan asas berpikir deduktif dan induktif dengan tehnik pengumpulan data dokumentasi,observasi dan wawancara.

Berdasarkan hasil penelitian dan deskripsi data yang dilakukan oleh peneliti mengenai sistem wali nikah dalam perkawinan adat baik yang di atur menurut hukum adat maupun menurut agama pada prinsipnya sama yakni merujuk pada garis kedekatan kerabat (nasab) dan hakim. Sistem perwalian dalam perkawinan adat di Desa Mbuju dilaksanakan berdasarkan pengakuan masyarakat dengan merujuk pada undang-undang perkawinan,(uu no.1 thn 1974), agama, adat kebiasaan sebagai perkawinan yang sah.

Kendala-kendala yang dihadapi dalam pelaksanaan perkawinan adat didesa mbuju hakim sangat sedikit sedangkan perwaliannya dilaksanakan oleh wali nasab yaitu wali yang ditetapkan berdasarkan atas dasar kedekatan kerabat serta wali nikah yang dilaksanakan dengan wali tunjuk.
\end{abstract}

\section{A. LATAR BELAKANG}

Perwalian dalam perkawinan tidak mudah karena, jika pihak dari perempuan tidak bersedia menjadi wali, maka perkawinan akan menjadi suatu persoalan yang membuat perkawinan tersebut berlarut-larut. Dalam perkawinan sendiri memiliki syarat-syarat atau aturan tertentu untuk menjadi wali. Apabila keluarga dari perempuan sendiri tidak sanggup memberikan kewaliannya atau yang biasa dikenal dengan bapak dari perempuan, jika wali yang pertama yaitu bapak meninggal dunia, dan memberikan kewaliannya kesaudara sekandung dari perempuan maupun saudara dari bapak, apabila perempuan ingin menikah harus segera memiliki wali karena dalam perkawinan yang paling penting harus ada wali, jika tidak ada wali maka perkawinan tersebut tidak sah. Perempuan masih memiliki wali nikah tetapi berada jauh wali nikah itu tidak bisa memberikan kewaliannya dengan tulisan melainkan dengan secara langsung, saudara dari perempuan tidak boleh memberikan kewaliannya lewat tulisan maka tidak sah. Wali dari pihak perempuan harus secara langsung melakukan kewajibannya sebagai wali, dimana perkawinan itu dilaksanakan oleh kedua mempelai pria dan wanita, dan wali nikah tersebut harus mendatangi secara langsung untuk memberikan kewaliannya agar perempuan tersebut memiliki status yang jelas, tidak menimbulkan fitnah di mata masyarakat pada umumnya, Departemen Agama RI,2001, dalam Maknah,(2004:18).

Adapun cara yang lebih mudah untuk mendapatkan wali nikah, keluarga perempuan tidak sangggup memberikan kewaliannya, maka pihak perempuan dapat mendatangi tokoh adat agar segera memberikan kewaliannya. Dalam agama Islam perkawinan itu apabila tidak dilaksanakan maka dikhawatirkan terjadinya perbuatan yang dilarang oleh agama yaitu, perbuatan zina.

Dari uraian di atas dapat disimpulkan bahwa wali nikah itu memiliki kedudukan yang sangat penting 
dalam perkawinan, dan tidak dapat dipungkiri karena walinikah merupakan unsur yang sangat menentukan perkawinan itu menjadi sah atau tidak sah dan unsurunsur yang lain.Pentingnya masalah seperti ini maka penulis mengangkat masalah perkawinan dengan fokus kajian pada masalah wali nikah dengan judul :"Studi Analisis Tentang Sistem Perwalian Dalam Perkawinan Adat di Desa MbujuKecamatanKilo Kabupaten Dompu"

\section{B. METODE PENELITIAN}

\section{METODE YANG DIGUNAKAN}

Metode yang digunakan adalah pendekatan deskriptif kualitatif yaitu suatu pendekatan yang dijelaskan untuk memperoleh informasi tentang gejala pada saat penelitian di lakukan Sarwono, (2006:412). Dalam hal ini pendekatan deskriptif kualitatif dapat dibagi menjadi beberapa jenis pendekatan diantaranya:

a. Fenomenologi/peristiwa atau gejala sosial yang alamiah dam situasi tertentu,

b. Historis/peristiwa atau kejadian pada masa lampau dengan menggunakan analisis logis,

c. Studi kasus/telaah secara mendalam tentang suatu kasus, dan kesimpulannya hanya berlaku terbatas pada kasus tertentu saja,

d. Etnografi/grounded theori/menyusun teori dengan menggunakan data lapangan. (Zainal Arifin, 2001: 58).

Dari uraian di atas, maka dapat disimpulkan bahwa dengan menggunakan metode pendekatan deskriptif kualitatif dimaksudkan semata-mata untuk menjelaskan "Pelaksanaan tentang studi analisis tentangperwalian dalam perkawinan adat di Desa Mbuju Kecamatan Kilo Kabupaten Dompu”.

\section{GAMBARAN UMUM LOKASI PENELITIAN}

Penelitian ini dilakukan di Desa Mbuju Kecamatan Kilo Kabupaten Dompu. Seluruh penduduknya beragama Islam. Mata pencaharian masyarakat Desa Mbuju, sebagian besar adalah nelayan, petani, dan berdagang, adapun batas-batas Desanya adalah sebagai berikut:
a. Sebelah Timur : Desa Taropo
b. Sebelah Barat : Desa Pali
c. Sebelah Utara :Desa Enca
d. Sebelah Selatan : Desa Taloko

Keadaan Penduduk Desa MbujuKecamatan Kilo Kabupaten Dompu dapat dilihat pada tabel I di bawah ini.

Keadaan Penduduk Desa Mbuju Tahun 2011/2012

\begin{tabular}{|c|c|c|c|c|}
\hline \multirow{2}{*}{ No } & \multirow{2}{*}{$\begin{array}{l}\text { Nama } \\
\text { Dusun }\end{array}$} & \multicolumn{2}{|c|}{ JenisKelamin } & \multirow{2}{*}{$\begin{array}{c}\text { Jumlah } \\
\text { orang }\end{array}$} \\
\hline & & $\begin{array}{l}\text { Laki- } \\
\text { Laki }\end{array}$ & $\begin{array}{c}\text { Perem } \\
\text { puan }\end{array}$ & \\
\hline 1 & 2 & 3 & 4 & 5 \\
\hline 1 & Mpolo & 100 & 150 & 250 \\
\hline 2 & Kambu & 320 & 470 & 790 \\
\hline 3 & Matompo & 55 & 65 & 120 \\
\hline \multirow[t]{2}{*}{4} & Mbuju & 510 & 605 & 1115 \\
\hline & Jumlah & 985 & 1290 & 2275 \\
\hline
\end{tabular}

Sumber Data: Data Monografi Desa Mbuju tahun 2012

\section{METODEPENENTUAN SUBJEK PENELITIAN}

Dalam penelitian kualitatif tidak menggunakan populasi, karena penelitian kualitatif berangkat dari kasus tertentu yang ada pada situasi sosial tertentu dan hasil kajiannya tidak akan diberlakukan ke populasi, tetapi ditransferkan ketempat lain pada situasi sosial yang memiliki kesamaan dengan situasi sosial pada kasus yang dipelajari. (sugiyono, 2005:2004).

Sampel dalam penelitian kualitatif bukan dinamakan responden, tetapi sebagai narasumber, atau partisipan, informen. Sampel dalam penelitian kualitatif, juga bukan disebut sampel statistik, tetapi sampel teoritis, karena tujuan penelitian kualitatif adalah untuk menghasilkan teori. Sampel dalam penelitian kualitatif juga disebut sebagai sampel konstruktif, karena dengan sumber data dari sampel itu dapat dikonstruksikan fenomena yang semula masih belum jelas.

Penelitian kualitatif tehnik sampling yang sering digunakan adalah purposive sampling, dan snowball sampling. Seperti telah dikemukakan bahwa, purposive sampling adalah tehnik pengambilan sampel sumber data dengan pertimbangan tertentu.Pertimbangan tertentu ini misalnya orang tersebut yang dianggap paling tahu tentang apa yang kita harapkan, atau mungkin dia sebagai penguasa sehingga akan memudahkan peneliti menjelajahi objek atau situasi sosial yang diteliti. Snowball sampling adalah tehnik pengambilan sampel sumber data, yang pada awalnya jumlahnya sedikit, lama-lama menjadi besar. Hal ini dilakukan karena dari jumlah sumber data yang sedikit itu tersebut belum memberikan data yang lengkap, maka mencari orang lain lagi yang dapat digunakan sebagai sumber data. Dengan demikian jumlah sampel sumber data akan semakin besar, seperti bola salju yang menggelinding lama-lama akan menjadi besar Sanipah,( 2005: 301).

Berdasarkan hal tersebut di atastehnik penganbilan sampeldalam penelitian ini peneliti menggunakan tehnik purposive sampling dan snowball sampling. Tehnik purposive sampling ini merupakan tehnik penganbilan sampel yang memberikan data yang lebih lengkap dan mereka tersebut jugadi pilih oleh peneliti yaitu: tokoh adat, tokoh agama, tokoh masyarakat pada umumnya. Sedangkan tehnik snowball sampling peneliti menggunakan sebagai penambahan data terhadap jumlah informan sebelum nya yang di rasakan oleh peneliti belum maksimaldalam memberikan data.Dalam penelitian ini yang menjadi subjek penelitian ini,masyarakat Desa mbuju.

\section{METODEPENGUMPULAN DATA}

Kegiatan pengumpulan data merupakan usaha secara operasional dalam pelaksanaan penelitian yang dapat memberikan pengaruh positif bagi pelaksanaan analisis dan interprestasi data.

Berkaitan dengan hal tersebut di atas, maka tehnik yang digunakan dalam pengumpulan data yang relevan dengan permasalahan penelitian ini adalah :

a. Observasi

Observasi merupakan aktifitas merekam kejadian atau peristiwa dan fenomena menggunakan alat indra, rekaman dalam observasi tidak seperti rekaman dengan kamera, atau alat elektronika, rekaman dalam observatsi 
telah diwarnai oleh latar belakang pengetahuan dan pengalaman orang yang melakukan observasi sehingga apa yang di rekam oleh dua orang belum tentu sama hasilnya.

Menurut Narkubo dan Achmadi,(2002:70), mengatakan bahwa observasi adalah "alat pengumpulan data yang dilakukan dengan cara mengamati dan mencatat secara sistimatis gejala-gejala yang diselidiki”.

Menurut Arikunto,(2003:132) bahwa observasi adalah sebagai kegiatan pemusatan perhatian terhadap suatu objek dengan menggunakan seluruh alat indera Margono,(2003:188) mengatakan bahwa observasi diartikan sebagai pengamatan dan pencatatan secara sistematis terhadap gejala yang nampak pada objek penelitian.

Secara umum observasi dapat dilakukan dengan 2 (dua) cara yaitu :

1) Observasi Partisipatif.

Observasi partisipatif adalah observasi (pengamatan) untuk mengambil bagian dalam kegiatan objeknya (Observasi) sebagaimana yang lain tidak nampak perbedaan dalam sikap.

2) Observasi non partisipatif

Observasi non partisipatif adalah observasi yang tidak melibatkan diri dalam observasi hanya pengamatan yang dilakukan secara sepintas pada saat tertentu kegiatan observasiSubagyo, ( 2004: 64-69).

Dalam penelitian ini, akan digunakan tehnik Observasi non partipatif, dimana peneliti akan melakukan pengamatan secara langsung didalam proses pelaksanaan penelitian, peneliti hanya mencatat datadata yang dibutuhkan sesuai dengan fenomena yang sebenarnya tanpa adanya penambahan atau pengurangan terhadap realitas yang terjadi, pada observasi ialah:

1) Bagaimana sistem perwaliandalam perkawinan adat di Desa Mbuju Kecamatan Kilo Kabupaten Dompu.

2) Kendala apa saja yang dihadapi wali nikah dalam perkawinan adat di Desa Mbuju Kecamatan Kilo Kabupaten Dompu.

b. Wawancara

Wawancara adalah bentuk komunikasi antara dua orang, melibatkan seseorang yang ingin memperoleh informasi dari orang lain dengan mengajukan pertanyaan-pertanyaan berdasarkan tujuan tertentu Muliyana,(2001: 108)

Adapun wawancara yang digunakan dalam wawancara ini tak terstruktur. Dimana susunan pertanyaan dan kata-kata dalam setiap pertanyaan yang dapat diubah saat wawancara, sesuaikan dengan kebutuhan dan kondisi saat wawancara dilakukan. Pengumpulan data dengan teknik ini bertujuan untuk memperoleh informasi dan keterangan baik dari subjek maupun informasi tentang Bagaimana kedudukan wali nikah dalam perkawinan adat di Desa Mbuju dan Kendala apa saja yang dihadapi wali nikah dalam perkawinan adat di Desa Mbuju.

\section{c. Dokumen}

Dokumen adalah gambaran penting berbentuk tulisan dan kariya- kariya monumental dari seorang. Menurut Sugiyono,(2000:325) merupakan cacatan peristiwa yang sudah berlalu.
1) Dokumen bisa berbentuk tulisan, gambar, atau karya-karya monumental dari seseorang. Secara umum dokumen dapat dilakukan dengan 1 (satu) cara yaitu:Dokumen yang berbentuk tulisan misalnya catatan harian, sejarah kehidupan (life histories), biografi, peraturan, kebijakan.

2) Dokumen yang berbentuk gambar, misalnya foto,gambar hidup ,sketsa dan lain-lain.

Dalam penelitian ini sebagai dokumennyaberbentuk tulisan misalnya catatan harian, sejarah kehidupan (life histories ),biografi, peraturan, kebijakanserta yang ada kaitannya dengan penelitian kualitatif.

\section{ANALISIS DATA}

Analisis data yang digunakan dalam penelitian ini adalah analisis model interaktif yang di kembangkan oleh Miles dan Huberman yang terdiri dari 3(tiga) komponen analisis, yaitu:

1) Reduksi data, yaitu data yang diperoleh dilokasi penelitian (data lapangan) dituangkan dalam uraian atau laporan yang lengkap dan terinci. Laporan lapangan akan direduksi, dirangkum, dipilih hal-hal yang pokok, difokuskan pada halhal yang penting, kemudian di cari tema atau polanya. Reduksi data berlangsung secara terus menerus selama proses penelitian berlangsung. Selama pengumpulan data berlangsung diadakan tahap reduksi data, selanjutnya membuat ringkasan, mengkode, menelusuri tema, membuat gagasan dan menulis memo.

2) Sajian data (display data), yaitu untuk memudahkan bagi peneliti untuk melihat gambaran secara keseluruhan atau bagian tertentu dari penelitian.

3) Penarikan kesimpulan, yaitu melakukan verifikasi secara terus menerus sepanjang proses penelitian berlangsung, mulai sejak awal memasuki lokasi penelitian selama proses pengumpulan data.

Dan penelitianberusaha untuk menganalisis dan mencari pola, tema, hubungan persamaan, hal-hal yang sering timbul, hipotesis dan sebagaianya yang dituangkan dalam kesimpulan yang masih bersifat relatif. Akan tetapi dengan bertambahnya data melalui proses verifikasi secara terus menerus maka akan diperoleh kesimpulan yang bersifat "Grounded”. Dengan kata lain kesimpulan senantiasa terus dilakukan verifikasi selama penelitian berlangsung, Miles dan Huberman,(1992: 1520).

Dengan uraian analisis di atas, maka dalam penyajian data dan analisa nantinya merujuk kepada poin-poin di atas, sehingga hasil penelitian untuk skripsi ini dapat terarah dalam pembahasan.

\section{HASIL DAN PEMBAHASAN \\ 1. DESKRIPSI DATA \\ a. Demografis}

Desa Mbujumerupakan salah satu Desa yang ada di Kecamatan Kilo Kabupaten Dompu. Desa Mbujuterbentuk dalam status Desa persiapan pada tahun 1960. Kepala Desa yang pertama H. Amajid Wi’i dan Sekretarisnya H. Usman.Kepemimpinan Kepala 
Desa dilanjutkan oleh Abdullah S.Pdserta sekertarisnya Amunir, yang pada awalnya menjabat sebagai Kepala Desa Taropodan pada saat kepemimpinannya Desa terdiri dari empat Dusun yaitu dapat dilihat pada tabelI di bawah ini:

Keadaan Penduduk Desa Mbuju Tahun 2011/2012

\begin{tabular}{|c|c|c|c|c|}
\hline \multirow[b]{2}{*}{ No } & \multirow{2}{*}{$\begin{array}{l}\text { Nama } \\
\text { Dusun }\end{array}$} & \multicolumn{2}{|c|}{ JenisKelamin } & \multirow{2}{*}{$\begin{array}{c}\text { Jumlah } \\
\text { orang }\end{array}$} \\
\hline & & $\begin{array}{l}\text { Laki- } \\
\text { Laki }\end{array}$ & $\begin{array}{l}\text { Perem } \\
\text { puan }\end{array}$ & \\
\hline 1 & Mpolo & 100 & 150 & 250 \\
\hline 2 & Kambu & 320 & 470 & 790 \\
\hline 3 & Matompo & 55 & 65 & 120 \\
\hline 4 & Mbuju & 510 & 605 & 1115 \\
\hline & Jumlah & 985 & 1290 & 2275 \\
\hline
\end{tabular}

Sumber Data: data monografi desa mbuju tahun 2012.

Adapun pekerjaan atau mata pencaharian penduduk Desa Mbuju dapat dilihat dalam tabel II di bawah ini:

Keadaan Mata Pencaharian

Penduduk Desa Mbuju Tahun 2012

\begin{tabular}{|c|l|c|c|}
\hline $\begin{array}{c}\mathrm{N} \\
\mathrm{O}\end{array}$ & \multicolumn{1}{|c|}{ Pekerjaan } & Jumlah(orang) & Keterangan \\
\hline 1 & 2 & 3 & 4 \\
\hline 1 & Pegawai negri & 53 & \\
\hline 2 & Pegawai swasta & 135 & \\
\hline 3 & Petani & 1.210 & \\
\hline 4 & Buruh & 50 & \\
\hline \multicolumn{2}{|c|}{ Jumlah } & \multicolumn{2}{|c|}{1448} \\
\hline
\end{tabular}

Sumber data: data monografi Desa Mbuju tahun 2012.

Sedangkan agama yang dianut penduduk Desa Mbuju dapat dilihat dalam tabel III bawah ini:

Keadaan Agama Penduduk Desa Mbuju Tahun 2012

\begin{tabular}{|c|c|c|c|}
\hline No & Agama & $\begin{array}{c}\text { Jumlah } \\
\text { (Orang) }\end{array}$ & $\begin{array}{c}\text { Keter } \\
\text { angan }\end{array}$ \\
\hline 1 & 2 & 3 & 4 \\
\hline 1 & Islam & 3580 & \\
\hline 2 & $\begin{array}{l}\text { Kristen } \\
\text { protestan }\end{array}$ & - & \\
\hline 3 & Hindu & - & \\
\hline 4 & Budha & - & \\
\hline 5 & $\begin{array}{l}\text { Kristen } \\
\text { Katolik }\end{array}$ & - & \\
\hline & Jumlah & 3580 \\
\hline
\end{tabular}

Sumber Data:Data Monografi Desa Mbuju Tahun 2012.

Dalam Menunjang Aktifitas Kehidupan Seharihari Masyarakat Desa Mbuju diberbagai desa dengan sarana dan prasarana yang telah tersedia, diantaranya dapat dilihat pada tabel IV di bawah ini:

Keadaan Sarana dan Prasarana Desa Mbuju Tahun 2012

\begin{tabular}{|c|l|c|}
\hline No & Sarana dan Prasarana & $\begin{array}{c}\text { Jum } \\
\text { lah }\end{array}$ \\
\hline 1 & Pendidikan SDN & 1 \\
\hline 2 & Kesehatan & \\
& - Posyandu di setiap dusun & 3 \\
& - Polindes & 1 \\
\hline 3 & prasarana dan perobatan & \\
\hline
\end{tabular}

Sumber Data: Data Monografi Desa Mbuju Tahun 2012

Dari data di atas sebagaimana diperoleh dari kantor urusan agama Kecamatan kilosebagai instansi yang kaitannya dengan masalah penelitian perkawinan yang tercatat menurut hukum dengan demikian tabel tersebut tidak memuat data perkawinan di bawah tangan.Berdasarkan data diatas sebagian besar wali nikah dalam perkawinan masyarakat Desa MbujuKecamatan Kilo dilaksanakan oleh wali nasabnya dan sebagian kecil wali dilaksanakan oleh hakim.

\section{b. Sistem Perwalian Dalam Perkawinan Adat DiDesa Mbuju}

Dalam hukum adat perwalian dalam perkawinan telah diatur tentang sistem atau tatacara wali nikah yakni dapat dilihat dari tingkat kedekatan antara kerabat, yaitu wali nasab dan wali hakim adapun beberapa antara lain wali terdiri dari empat kelompok yakni:

1) Kerabatlaki-laki dalam garis lurus keatas yakni ayah, kakekdari pihak ayah dan seterusnya.

2) Kelompok kerabat laki-laki sekandung atau saudara laki-laki seayah dan keturunan laki-laki dari meraka.

3) Kelompok saudara kerabat paman,yakni saudara laki-laki sekandung dari ayah atau saudara lakilaki seayah dari ayah dan keturunan laki-laki dari mereka.

4) Kelompok kerabat saudara laki-laki sekandung atau seayah dan dari keturunan laki-laki mereka.

Dan apabila satu kelompok wali nikah terdapat beberapa orang yang sama kedudukannya sebagai wali nikah, maka yang paling berhak adalah yang paling dekat dengan pihak perempuan yang hendak menikah. kemudian bila dalam satu kelompok sama derajatnya yang paling berhak menjadi wali nikah adalah kerabat kandung dari kerabat yang hanya seayah mereka samasama berhak sebagai wali nikah dan dapat diuraikan dalam sistem perwalian menurut ketentuan hukum adat adalah sebagai berikut:

1) Wali nikah harus orang Islam yang berarti orang yang bukan Islam tidak dapat dijadikan wali nikah

2) Wali nikah harus orang yang mencapai umur baligh dan orang yang belum baligh tidak dapat dijadikan wali nikah

3) Wali nikah harus sempurna akal pikirannya dan orang yang gila tidak dapat dijadikan wali nikah

4) Wali nikah harus terdiri dari orang laki-laki dan perempuan tidak dapat dijadikan wali nikah

5) Wali harus terdiri dari orang yang taat kepada ajaran agama serta orang tahu memilih jodoh pada anaknya

Urutan tersebut harus disesuaikan dengan urutan-urutan sesuai tingkat dan kedudukan sebagai waliadapun urutan itu dilihat dari kedekatan sebagai kerabat dari perempuan yang diwalikannya, seperti bapak lebih utama dari pada kakek dan seterusnya keatas dan juga lebih utama pada paman baik paman dari saudara kandung paman.

Kalaupun ada perbedaan terlihat ketika dalam perkawinan tersebut dihadapkan kesulitan mendapatkan wali nikah dan tidak memenuhi syarat sebagaimana diatur menurut kententuan hukum tidak dapat dilaksanakan menurut hukum adat dalam kondisi seperti ini masyarakat Desa Mbuju cendrung untuk melaksanakan perkawinan dibawah tangan dengan perkawinan seperti ini perwalian dapat dilaksanakan dengan wali hakim tetapi hakim yang ditentukan dalam keadaan darurat dan sering disebut wali tunjuk wali tunjuk ini merupakan wali nikah yang ditunjuk langsungoleh calon mempelai wanita dengan syarat yang 
ditunjuk tersebut adalah seorang yang memenuhi syarat sebagai wali.

Selain itu perbedaan juga terlihat pada proses untuk memperoleh wali nikah dimana pelaksanaanya sangat khas sebagai wajah Budaya Desa Mbujusebelum minang dilangsungkan maka pihak laki-laki merembuk terlebih dahulu bagaimana tatacara dalam Lao Kai (minang), adapun tatacaranya adalah:

1) Lao Kai (minang) pertamamerupakan kegiatan pertama yanng dilaksanakan oleh pihak laki-laki dengan beberapa utusan (minimal dua orang) untuk memberitahukan pihak keluarga perempuan yang menyatakan, si Anu (calon mempelai perempuan) berkehendak untuk kawin dengan si Anu (calon mempelai laki-laki) dengan menyebutkan identitas dari laki-laki tersebut dan identitas keluarga laki-laki dan memberitahukan bahwa calon mempelai perempuan tersebut dalam keadaan diamankan oleh keluarga pihak laki-laki pemberitahuan ini dilaksanakan melalui kepala kampung sebagai ketua adat setempat setelah kedua belah pihak bersedia untuk menikah yang dibuktikan dengan telah dibawanya perempuan oleh pihak laki-laki meninggalkan sanak saudaranya menuju suatu tempat dimana pihak laki-laki tinggal.

2) Setelah Lao Kai pertama maka pihak laki-laki dapat melanjutkan kegiatan lao kai (minang)kedua dengan utusan minimal dua orang dan salah satunnya tidak boleh sebagai utusan untuk kedua kalinya. Lao kai kedua bertujuan untuk memohon memanggil wali, utusan ini dapat diterima atau ditolak tergantung bagaimana pihak perempuan menilainyaadapun yang dinilai adalah sopan santun, tutur kata, pakaian, dan kelengkapannyadan hal-hal lain yang kaitannya dengan tata krama adat jika utusan ditrima maka utusan tersebut dapat langsung membicarakan mengenai wali nikah beban pihak laki-laki untuk menyelesaikan perkawinan dan hal-hal lain yang dipandang perlu seperti mas kawin dan jumlah hasilnya disampaikan kepada pihak keluarga lakilaki untuk kemudian dilaksanakan akad nikah. Dan bila utusan ditolak maka dapat dilaksanakan kembali esok hari atau waktu yang ditetapkan oleh keluarga perempuan.

3) Lao kai ketiga dapat dilaksanakan berkali-kali sehingga kapanlao kai (pinang) terebut dapat diterima pihak keluarga perempuan. Dan dalam hal ini pihak laki-laki dapat melaksanakan lao kai cukup tiga kali saja dan tidak melanjutkan untuk berikutnya bila kejadian seperti ini terjadi berarti pihak laki-laki menganggap pihak perempuan mempersulit jalannya perkawinan dan dapat memohon pergantian wali kepengadilan Agama dan setelah beberapa lama utusan dari pihak lakilaki tidak datang maka maka pihak perempuan jika berkepentingan dapat berkirim salam kepada pihak laki-laki agar utusan segera datang untuk membahas tentang berbagai masalah mengenai masalah perkawinan yang sedang dihadapinya dalam hal ini biasanya pihak perempuan siap memberi wali nikah.

Dari uraian diatas dapat disimpulkan bahwa dalam meminang merupakan unsur yang sangat penting untuk memudahkan seorang dalam melaksanakan perkawinan dilihat dari bentuk minang umumnya sangat ditentukan oleh sikap dari utusan pihak mempelai lakilaki dan mampu memahami aturan atau tatacara bagaimana melaksanakan minang yangbaiksetelah minang diterima maka utusan menyampaikan persyaratan yang diinginkan oleh pihak perempuan kepada kelurga pihak dari laki-laki apakah persyaratan yang diinginkan oleh pihak perempuan bisa diterima atau tidak jika kesimpulan sudah ada maka utusan kembali kekeluarga perempuan dan menyampaikan persyaratan itu sudah diterima oleh pihak laki-laki.

Wali nikah dalam perkawinan Adat baik yang di atur menurut agama ,maupun menurut hukumadat pada prinsipnya sama yakni merujuk pada garis kedekatan kerabat (nasab) dan hakim. Hal ini adalah untuk mempermudah jalannnya perkawinan karena agama Islam mengajarkan supaya tidak ada kesulitan dalam melaksanakan perkawinan,karena perkawinan itu merupakan peristiwa yang penting dalam kehidupan manusia dan merupakan suatu kebutuhan mutlak baik ditinjau dari segi biologis maupun dari segi agama yaitu untuk melestarikan jenisnya dan kepentingan di dalam melaksanakan perkawinan wali nikah dalam kedudukannya tidak selalu ada dan tidak sepenuhnya syarat-syarat tertentu untuk menjadi wali nikah sehingga dapat melaksanakan perwalian seseorang tidak memiliki kesempatan. Dalam hal ini untuk melaksanakan perkawinan wali nikah dapat dilaksanakan oleh wali nikah tingkat tingkatan berikutnya sepanjang wali dalam urutan itu memenuhi syarat. Wali nikah setelah Bapakkakekdan seterusnya, saudara kandung. Dan wali nikah saudara dari sebapak wali pada tingkatan ini dapat bertindak sebagai wali nikah setelah saudara sekandung tidak ada atau enggan meberikan perwaliannya dan begitu seterusnya hingga tingkat urutan terakhir. Kemudian jika ada wali dalam tingkatan yang sama maka salah satunya dapat melaksanakan perwaliannya dengan izin perempuan yang hendak kawin tersebut kalaupun tanpa persetujuan wali yang lainnya jika wali nikah dalam tingkatnya adalah calon suami maka yang berhak menjadi wali nikah pada perkawinan itu adalah wali pada tingkatan berikutnnya. Kalau wali nikah terdekat dengan anak perempuan itu bertempat tinggal jauh dari tempat perempuan yang hendak melaksanakan perkawinan itu dan di tempat itu tidak ada wakilnya maka yang menjadi wali nikah pada perkawinan pada itu hakim bukan wali nika pada tingkatan berikutnya karena walinikah pada tingkatan ada tetapi kesulitan memberi perwaliannya.Dalam melaksanakan perwaliannya seseorang harus meminta izin terlebih dahulu kepada perempuan yang hendak dikawinkan hal ini berlaku pada semua tingkatan wali nikah kecuali wali nikah mujbir. Mengenai izin ini berlaku juga kepada wali hakim yaitu wali hakim hanya dapat melaksanakan perwalian atas seizin perempuan yang berhendak menikah tersebut dan izin dari perempuan itu sah bila perempuan itu telah berumur baligh.

Wali nikah merupakan hak dari seorang perempuan terhadap ayahnya dan keluarga dalam garis lurus keatas dari kerabat laki-laki dan sifatnya sangat asasi asasi yang tidak diperdebatkan tak kala perempuan itu kawin melainkan segera mungkin agar pelaksanaan perkawinan itu tidak dipersulit karena mempersulit perkawinan itu suatu perbuatan yang bertentangan dengan ajaran Islam. 
Wali nikah adalah menempati kedudukan sebagai syarat sah dan rukun dalam perkawinan dengan demikian tidak ada alasan bagi suatu perkawinan tanpa wali nikah. sepanjang sejarah di Desa Mbuju tidak pernah ada perkawinan tanpa wali nikah karena penduduk Desa Mbuju adalah seluruhnya beragama Islam sehingga dalam melaksanakan perkawinan mutlak merujuk pada ajaran agama Islamdan kaitkan dengan hukum Adat karna perkawinan berlaku sebagai peraturan dalam kehidupan masyarakat.

Wali nikah dalam perkawinan adalah mutlaksedangkan bagi seseorang yang tidak ada wali nikahnya atau tidak jelas wali nikahnya dan hakim sebagai wali pengganti tidak dapat mengabulkan wali pengganti maka dalam perkawinan seperti ini wali nikah dapat dilaksanakan dengan wali tunjuk yaitu wali nikah ini ditunjuk oleh perempuan yang akan menikah tersebut. Wali yang ini dianggap sebagai hakim dalam keadaan darurat dan harus memenuhi syarat sebagaimana syariatkan Islamdalam hal ini wali tersebut harus sudah baligh, Islamlaki -laki, taat beragama jujurdan adil. Hal ini dilaksanakan atas pertimbangan akibat dari penundaan perkawinan karena menurut adat Desa Mbuju dalam hal pelanggaran oleh kedua belah pihak karena penundaan perkawinan yang relatif lama adalah tanggun jawab moral lingkungan. Oleh karena itu sedapat mungkin masalah perkawinan dituntut secara adat untuk segera diselesaikan.

Penundaan perkawinan hanya terjadi ketika calon mempelai tidak dapat memenuhi syarat-syarat yang diatur oleh hukum adat keadaan seperti ini maka perkawinan dilaksakan jika syarat dan rukun perkawinan seperti ada wali nikah ada saksi ada calon suami istri dan ijab kabul. Perkawinan seperti ini sudah dapat diterima sebagai pasangan suami istri,hanya saja secara hukum tidak memiliki bukti otentik berupa akte nikah dan tidak memiliki akibat hukum berupa pengakuan dan perlindungan hukum positif.Karna perkawinan seperti ini merupakan hak dari seorang perempuan terhadap ayahnya dan keluarga dalam garis lurus keatas dari kerabat laki-laki dan sifatnya sangat asasi yang tidak diperdebatkan takkala perempuan itu kawin. Melainkan segera mungkin agar pelaksanaan perkawinan itu tidak dipersulit karena mempersulit perkawinan itu suatu perbuatan yang bertentangan dengan ajaran Islam. Wali nikah adalah menempati kedudukan sebagai syarat sah dan rukun dalam perkawinan dengan demikian tidak ada alasan bagi suatu perkawinan tanpa wali nikah sepanjang sejarah di Desa Mbuju tidak pernah ada perkawinan tanpa wali nikah karena pendudukDesa Mbuju adalah seluruhnya mayoritas Islamsehingga dalam melaksanakan perkawinan mutlak merujuk pada ajaranIslam. Dan hukum adat dalam mengatur perkawinan yang berlaku sebagai peraturan dalam kehidupan masyarakat dalam perkawinan adalah mutlak sedangkan bagi seseorang yang tidak ada wali nikahnya atau tidak jelas wali nikahnya dan hakim sebagai wali pengganti tidak dapat mengabulkan wali pengganti maka dalam perkawinan seperti ini wali nikah dapat dilaksanakan dengan wali tunjuk yaitu wali nikah ini ditunjuk oleh perempuan yang akan menikah tersebut. Wali yang ini dianggap sebagai hakim dalam keadaan darurat dan harus memenuhi syarat sebagaimana syariatkan Islamdalam hal ini wali tersebut harus sudah baligh, Islam laki-laki taat beragama jujur dan adil. Hal ini dilaksanakan atas pertimbangan akibat dari penundaan perkawinan. Karena menurut adat Desa Mbuju dalam hal pelanggaran oleh kedua belah pihak karena penundaan perkawinan yang relatif lama adalah tanggun jawab moral lingkungan. Oleh karena itu sedapat mungkin masalah perkawinan dituntut secara adat untuk segerah diselesaikan.

Dalam pandangan hukum adat tentangwali nikah dalam perkawinan pada azasnya merupakan suatu kajian agama dalam hal ini sangatlah gampang dan mudah untuk diketahuisebagai umat Islamtentang wali nikah ini sudah jelas dalam syariat Islam. Dan salah satu yang sangat prinsip mengenai wali nikah dalam perkawinan adalah merupakan salah satu unsur dalam syarat dan rukun perkawinan tentu sekali mutlak harus ada. Dalam hal wali nikah tidak ada atau ada tetapi sulit keadaan seperti adat di Desa Mbujutidak akan sampai mempersulit jalannnya perkawinan melainkan sudah ada penyelesaian yang sangat bijaksana seperti ada yang disebut wali hakim dan selanjutnya ketika wali hakim menurut hukum adat itu tidak dapat diperoleh maka wali nikah itu dapat ditunjuk langsung oleh pihak perenpuan tersebut kepada orang yang memenuhi syarat hukum dan wali seperti ini sering disebut wali tunjuk.Wali tunjuk ini sering juga digunakan dalam perkawinan di Desa Mbuju sebagai jalang keluar ketika masalah wali dalam perkawinan tidak ada dan wali hakim menurut UU No. 1 tahun 1974 tidak dapat diperoleh karena tidak lenkapnya syarat-syarat yang harus ditunjuk oleh pihak berkepentingan.Wali tunjuk itu diangap sebagai wali hakim karena syaratnya mereka yang ditunjuk ituadalahorang yang sudah baligh, waras akalnya,taat beragama,jujur dan adil dan tidak dipaksa.

Wali nikah dari seorang perempuan yang hendak menikah adalah ayahnya dalam hal ayah telah meninggal maka perwalian itu beralih kepada kakeknya kemudian kepada pamanya saudara laki-laki dan kesemua itu ditetapkan dalam garis keturunan laki-laki dari pihak laki-laki. Jika terjadi perwalian yang disebutkan itu tidak ada atau sulit dihubungi maka untuk mempermudah pelaksanaan perkawinan itu wali nikah dapat dilaksanakan oleh wali hakim. Karena adat tidak menghendaki kesulitan dalam perkawinan ini kaitannya dengan kepentingan hubungan yang aman dan bebas dari perbuatan tercela.Dan adanya persoalan yang sangat rumit dalam hal wali nikah seseorang maka untuk memperoleh kejelasan yang memuaskan menurut adat di Desa Mbuju ini kembali kepada pendapat tokoh agama sebagai ahli agama Islam, karena masyarakat Desa Mbuju adalah seluruhnya mayoritas Islam.

Perwalian pada umumnya hanya merujuk pada prinsi-prinsip Islamkarena masyarakat Desa Mbuju pada umumnya mayoritasIslamsehingga dengan alasan apapun kehidupannya diwarnai dengan prinsip-prinsip Islamtermasuk dalam hal perkawinantetapi kadangkadang acara dalam pelaksanaan adat perkawinan itu dilaksanakan secara khas dan dikuatkan oleh masyarakat.

\section{1) Lao kai (lamaran)}

Dalam hal wali nikah disini ada proses yang sangat khas dan sangat dikuatkan masyarakat Desa Mbuju. Adapun proses itu adalah dimulai dari proses lao kai (lamaran) pertama lao kai kedua dan ketiga dan kadang-kadang lao kai dilaksanakan sampai tiga kali. 
Dari beberapa penjelasan diatas dapat dirumuskan bahwa mengenai wali nikah dalam perkawinan adat baik yang diatur menurut hukum adat maupun menurut agama pada prinsipnya sama yakni merujuk pada garis kedekatan kerabat (nasab) dan hakim. Hal ini adalah untuk mempermudah jalannya perkawinan karena agama Islammengajarkan supaya tidak ada kesulitan dalam melaksanakan perkawinankarena perkawian itu merupakan peristiwa yang pentingdalam kehidupan manusia dan merupakan suatu kebutuhan mutlak baik ditinjau dari segi biologis maupun dari segi agama yaitu untuk menlestarikan jenisnya dan kepentingan di dalam melaksanakan perkawinan wali nikah dalam kedudukannya tidak selalu ada dan tidak sepenuhnya syarat-syarat tertentu untuk menjadi wali nikah sehingga dapat melaksanakan perwalian seseorang tidak memiliki kesempatan. Dalam hal ini untuk melaksanakan perkawinan dapat dilaksanakan oleh wali nikah tingkat tingkatan berikutnya sepanjang wali dalam urutan itu memenuhi syarat. Wali nikah setelah Bapak kakek dan seterusnya, saudara kandung dan wali nikah saudara dari sebapak wali pada tingkatan ini dapat bertindak sebagai wali nikah setelah saudara sekandung tidak ada atau enggan memberikan perwaliannya dan begitu seterusnya hingga tingkat urutan terakhir Kemudian jika ada wali dalam tingkatan yang sama maka salah satunya dapat melaksanakan perwaliannya dengan izin perempuan yang hendak kawin tersebut kalaupun tanpa persetujuan wali yang lainnya. Bila wali nikah dalam tingkatnya adalah calon suami maka yang berhak menjadi wali nikah pada perkawinan itu adalah wali pada tingkatan berikutnya. Kalau wali nikah terdekat dengan anak perempuan itu bertempat tinggal jauh dari tempat perempuan yang hendak melaksanakan perkawinan itu dan di tempat itu tidak ada wakilnya maka yang menjadi wali nikah pada perkawinan pada saat itu hakim bukan wali nikah pada tingkatan berikutnya karena wali nikah pada tingkatan ada tetapi kesulitan dalam memberi perwaliannya. Dalam melaksanakan perwaliannya seseorang harus meminta izin terlebih dahulu kepada perempuan yang hendak dikawinkan hal ini berlaku pada semua tingkatan wali nikah kecuali wali nikah mujbir mengenai izin ini berlaku juga kepada wali hakim yaitu wali hakim hanya dapat melaksanakan perwalian atas seizin perempuan yang berhendak menikah tersebut dan izin dari perempuan itu sah bila perempuan itu telah berumur baligh.

Kegiatan ini merupakan langkah awal yang dilakukan oleh orang tua pemuda guna mencari seorang gadis yang cocok untuk dijadikan "dou sodi"(tunangan) putranya. Orang tua atau keluarga dekat dari pemuda akan berkunjung ke rumah orang tua gadis idaman putranya, pihak orang tua pemuda akan meminta keterangan dari pihak orang tua gadis tentang status putrinya, apakah sebelumnya sudah menjadi tunangan dari pemuda lain atau belum, seandainya belum, maka ada peluang bagi pihak orang tua pemuda untuk meminang gadis tersebut. Upaya yang dilakukan oleh pihak orang tua untuk mencari jodoh putranya hanya diketahuai oleh keluarga terdekat belum diumumkan kepada seluruh keluarga karna hal ini masih sifatnya rahasia.

Setelah mendapat kepastian bahwa gadis tersebut belum dilamar atau menjadi tunangan putra lain maka pihak keluarga pemuda akan melakukan kunjungan kedua kerumah orang tua si gadis sebagai tindak lanjut dari laokai. Dalam kunjungan ini pihak orang tua pemuda biasannya akan diwakili oleh seorang tokoh adat yang biasanya disebut "ompu panat", didampingi oleh beberapa orang keluarga terdekat ompu panati adalah seorang tokoh adat yang dipandang ahli dalam pinang meminang gadis dia juga biasanya ahli dalam berpantun dan bersyair.

Dengan menjunjung tinggi tata krama disertai untaian indah lagi nan sopan ompu panati menyampaikan lamaran orang tua pemuda kepada orang tua si gadis dengan kata lain ompu panati mengeluarkan isi hati orang tua pemuda kepada orang tua si gadis karna itu kegiatan ini dinamakan katanda nggahi(mengikrar kata hati).

\section{2) Katanda Nggahi (Mengikrar Kata Hati)}

Selanjutnya bila lamaran diterima, maka hasilnya akan diumumkan kepada seluruh keluarga, kemudian proses ini akan dilaporkan kepada pimpinan sara huku (sara hukum) yaitu lebe tokoh adat setempat. Mulai saat itu pemuda tersebut menjadi dou sodi atau tunangan gadis tersebut, begitupun sebaliknya sejak saat itu antara kedua keluarga mereka saling kunjung mengunjungi atau mempererat tali silaturahim guna meningkatkan hubungan baik antara keluarga maka keluarga terus meningkatkan tali silaturrahim. Kegiatan yang dilakukan oleh keluarga tersebut dinamakan pita nggahi (bersatu dalam ikatan).

\section{3) Pita Nggahi(Bersatu Dalam Ikatan)}

Setelah kedua keluarga tersebut menyepakati antara hubungan kedua anaknya maka pemuda yang menjadi dou sodi/tunangan anaknya diperbolehkan untuk tinggal sementara dirumah calon mertuanya tersebut selama pelaksanaan perkawinan belum dilangsungkan atau biasa disebut ngge,e nuru (tinggal bersama calon mertua).

\section{4) Ngge'e Nuru (Tinggal Bersama Calon Mertua)}

Selama pemuda tinggal dirumahcalon mertuanya dan selama itu pula pemuda membantu apapun jenis kegiatan yang akan dilakukan dirumah tersebut, setelah melihat calon menantunya sungguhsungguh berkerja dan ingin menikah dengan anaknya maka orang tua gadis mengadakan mbolo weki (bermusyawarah).

\section{5) Mbolo Weki (Bermusyawarah)}

Dalam acara mbolo weki tersebut pihak keluarga laki-laki bersama warga yang diundang dengan menggunakan undangan thari sebelum acara mbolo weki dilaksanakan, mboloweki tersebut guna untuk memusyawarahkan dan menemukan solusi tentang kapan diantarkannya co’i untuk gadis tersebut setelah solusi didapatkan dalam musyawarah tersebut maka tindak lanjut dari mbolo weki tersebut untuk keesokan harinya adalah wa'a co'i.

\section{6) Wa'a Co'i (antar mahar)}

Pihak keluarga sebulum mengantarkan mahar kekeluarga perempuan terlebih dahulu mengumumkan kepada seluruh warga dikampung tersebut bahwa nanti akan diantar kan mahar untuk calon menantunya dikampung sebelah, disitu pihak keluarga yang berhajat, meminta partisipasi warga untuk ikut serta meramaikan acara pengantaran mahar anaknya tersebut.

Setelah diantarkanya co’i(mahar) disana pihak keluarga pemuda bermusyawarah lagi dengan keluarga perempuan guna mendapatkan solusi kapan hari-hari baik yang menurut kedua keluarga yang berhajat untuk 
dilaksanakan pernikahan. Setelah solusi didapatkan dalam musyawarah tersebut maka tindak lanjut dari pihak keluarga akan mengadakan acara(kapanca) pernikahan.

\section{7) Kapanca(Malam Pancar)}

Sebagai tindak lanjut dari wa'a co’i, dalam acara kapanca tersebut biasanya diiringi dengan gambus dan diiringi dengan biola, tarian, dan alunan rebana, dan zikir dari masyarakat didesa tersebut setelah kapanca dilakukan maka keesokan harinya adalahlafa (aqad).

\section{8) Lafa (Aqad)}

Adalah puncak prosesi Adat Dompu pelaksanaan ijab harus dilaksanakan ditempat ibadah seperti dimesjid dan dihadapan para ulama cara pelaksanaan lafa/aqad adalah calon mempelai pria duduk di atas tikar menghadap wali nikah kearah kiblat dan sebelum dilakukannya ijab kabul biasanya wali menasehati keduamempelaiterlebihdahulusetelah itu wali mengucapkan dua kalimat syahadat dan isrtigfar sebanyak 3x, lalu memanggil nama mempelai pria (Ibrahim) misalnya, dan bersalaman tangan kanan ditutupi dengan sapu tangan warna putih yang melambangkan kesucian hati calon mempelai dan berkata dalam bahasa Dompunya "nahu ka nika kunggomi (Ibrahim) la'o ana nahu la (Eti Yuliati Binti $\mathrm{H}$. Arifin) kai coi rawa'amu dan calon mempelai pria menjawab dengan bahasa Dompunya mada ku tarima nika na la (Eti Yuliati Binti H. Arifin) kai co’i bune ra nggahi.

Apabila ijab itu disetujui dan dibenarkan oleh dua orang saksi lalu wali mengatakan kepada saksi sah dan mereka membalasnya sah, sah maka selesailah upacara perkawinan itu.

Jadi dalam pelaksanaan upacara perkawinan adat boleh mengadakan perayaan dengan musik-musik kesenian asal saja tidak bercampur aduk dengan prilaku maksiat seperti membiarkan perjudian, minuman keras, berpakaian yang tidak sopan.

Dari rangkaian upacara dalam-perkawinan adat tersebut mengandung makna yang mendalam untuk diterapkan dan dilestarikan dalam hidup dan kehidupan sehari-hari seluruh rangkaian upacara tersebut itu sesungguhnya sesuai dengan ajaran agamaadat dan norma-norma yang berlaku di masyarakat.

Dalam tatacara pelaksanaan perwalian dalam perkawinan adat di Desa Mbuju yakni seorang perempuan meminta persetujuan kepada bapaknya agar segera memberikan perwaliannya, karena yang berhak menjadi wali adalah bapak dari perempuan jika wali berada jauh atau meninggal maka saudara laki-laki berhak menjadi wali dari perempuan meskipun walinya belum baligh atau dewasa maka anak tersebut harus bersedia menjadi wali nikah dari saudara perempuannya.Dan ada juga wali nikah dari seorang perempuan yang hendak menikah adalah ayahnya. Dalam hal ayah telah meninggal maka perwalian itu beralih kepada kakeknya kemudian kepada pamannya,saudara laki-laki dan kesemua itu ditetapkan dalam garis keturunan laki-laki dari pihak laki-laki. Jika terjadi perwalian yang disebutkan itu tidak ada atau sulit dihubungi maka untuk mempermudah pelaksanaan perkawinan itu wali nikah dapat dilaksanakan oleh wali hakimkarena adat tidak menghendaki kesulitan dalam perkawinan ini kaitannya dengan kepentingan hubungan yang aman dan bebas dari perbuatan tercela.Dan adanya persoalan yang sangat rumit dalam hal wali nikah seseorang maka untuk memperoleh kejelasan yang memuaskanmenurutadatdiDesaMbuju ini kembali kepada pendapat pemuka agama sebagai ahli agama Islamkarena masyarakat Desa Mbuju adalah seluruhnya beragama Islam.

Berdasarkan uraian diatas dapat disimpulkan bahwa pada prinsipnya sistem wali nikah dalam pelaksanaannya di Desa Mbuju baik menurut adat agama maupun hukum positif adalah sama yaitu berdasarkan kedekatannya kerabat dan hakim. Menurut adat di Desa Mbuju sistem wali nikah yang dianutnya adalah sistem wali nikah sebagaimana diatur dalam hukum adathanya saja untuk mendapatkan wali nikah tersebut dilaksanakan melalui proses tertentu yang sangat khas.Namun pada dasarnya tidak bertentangan dengan yang diatur dalam undang-undang perkawinan tersebut.

\section{c. Kendala Yang Dihadapi Perwalian Dalam \\ PerkawinanAdat}

Di dalam perkawinan adat sering kali dihadapkan dengan kendala-kendala yang bisa menunda bahkan membatalkan perkawinan itu seperti tidak adanya seorang wali.

\section{1) Perkawinan yang dihadapkan kesulitan wali} nikah.

Perkawinansudahjelastidakdapatdilaksanak ansebagaimanaperkawinanbiasanya,dalamartianper kawinanini tidak dapat dilaksanakan karena wali tidak ada. Sebagaimana sistem wali nikah baik menurut hukum adat maupun, menurut agama Islamdi Desa Mbuju maka perkawinan ini dilaksanakan dengan wali hakim. Adapun untuk mendapatkan pergantian wali sebagaimana yang diatur menurut hukum adatwali hakim itu akan dikabulkan jika memenuhi syarat-syarat tertentu, baik syarat-syarat sebagaimana syariat Islam maupun syarat administrasi.

Contoh: kasus perkawinan dengan seorang imigran asal malasiya yang tidak memenuhi syarat yang lengkap supaya perkawinan ini dilaksanakan,maka kepala adat mengajukan laporan agar masalah ini dilaporkan keperwakilan malasiya di Tanjung Pinang karena perwakilan adalah perkawinan campuran antar negara dihadapkan oleh kesulitan seperti ini maka perkawinan dilaksanakan tampa pencatatan oleh PPPN (dibawah tangan) yaitu dengan wali tunjuk dimana kepada seseorang sebagai wali.

2) Perkawinan yang dilaksanakan tanpa meminta izin dari calon mempelai wanita.

Di antara dari kedua pihak initerikat hubungan keluarga halal nikah(misan) dan perkawinan mereka dilaksanakan olehwali nikahnya tanpa meminta izin terlebih dahulu kepada calon mempelai perempuan. Hal ini dilaksanakan atas dasar ketentuan Islam,dan hukum adat yang membenarkan perkawinan dengan tidak meminta izin terlebih dahulu kepada pihak calon mempelai dengan syarat pemohon tersebut masih gadis dan walinya dalam kedudukan wali nikah mujbir (ayah kandung, ayah dari, kakek dari ayah dan seterusnya).

Dan dalamperkawinan ini yang melaksanakan perwaliannyayaitu ayah kandung dari calon mempelai perempuan dengan demikian wali 
nikah tersebut berkedudukan sebagai wali nikah mujbir. Selain wali nikah dalam kedudukan tersebut tidak dapat melaksanakan perwalianya tanpa meminta izin terlebih dahulu dari pihak calon mempelai perempuan. Dan perkawinan seperti ini di Desa Mbuju disebut kawin adat (nika tua).

Wali nikah menurut adat di Desa Mbuju adalah seorang perempuan yang dikawin paksakan oleh orang tuanya, yaitu lao pata ulu(silaturahim) ini dilaksanakan dengan terlebih dahulu menanyakan hukumnya kepada. Haji usman selaku tokoh agama dan dinyatakan boleh atau sahhal ini dapat dilaksanakan asalkan pihak yang dikawinkan itu masih gadis sedangkan bila ia sudah pernah kawin maka kawin paksa baginya tidak dapat dilaksanakankarena orang yang sudah pernah kawin dianggap sudah mampu menentukan jodohnya dan perkawinan tanpa izin (orang tua) merupakan perkawinan yang dapat diterima adat dan sering dilaksanakan oleh masyarakat Desa Mbuju pada umumnya.

3) Perkawinan yang dihadapkan masalah karena terikat perkawinan sebelumnya.

Dalam hal ini calon suami masih terikat perkawinan dari istrinya yang bernama nurhayati yang bekerja di luar negeri (Saudi Arabia) sehingga untuk melaksaanakan perkawinan tercatat sangat sulitoleh karena itu untuk mempercepat pelaksanaan perkawinannya maka walinya bersedia memberikan perwaliannya kalaupun dengan perkawinan dibawah tangan dengan demikian perkawinan ini dilaksanakan di bawah tangan.

Pada umumnya masyarakatDesa Mbuju kecamatan Kilo Kabupaten Dompumenginginkan pelaksanaan perkawinan dirumah masingmasingakan tetapi jadwal pelaksanaan nikah tidak dapat ditepati secara disiplin karena keterbatasan tenaga dan tempat dalam melaksanakan perkawinan tersebut, adapun kendala yang timbul sebelum dilangsungkan perkawinandi desa tersebut adalah Hidi Paruga (tempat paruga/tenda)yaitu untuk berlangsungnya suatu acara resepsi,Jika dibandingkan dengan desa lain di Desa Mbujutidak memiliki tempat khusus/lapangan untuk tempat resepsi pernikahan, warga didesa tersebut hanya menggunakan lapangan sekolahitupun setelah siswa-siswi pulang sekolah dan biasanya acara resepsi dilangsungkan pada sore hari sekitar jam 15.00 wita,pada saat dibangunnya paruga/tenda untuk persiapan resepsi pernikahan masyarakat di sana sangat antusias untuk bergotong royong guna membantu membangunkan tenda yang terbuat dari bambu dan diatapi dengan terpal untuk keluarga yang berhajat menengah kebawahdan bagi keluarga yang menengah keatas mereka tidak repot-repot menyuruh warganya untuk membangun paruga dengan menggunakan bambu tetapi meraka membayar paruga jadi yang dipesan khusus dan tinggal terima jadi saja hanya saja menggunakan tempat yang sama.

Kemudian kendala yang dihadapi seorang wali dalam melakukan perkawinan yang perwaliannya dilaksanakan oleh hakim sangat sedikit sedangkan sebagai besar perkawinan di Desa Mbuju perwaliannya dilaksanakan oleh wali nasab yaitu wali yang ditetapkan atas dasar kedekatan kerabat.

Sebagianya lagi kendala yang muncul ditengah-tengah masayarakat Desa Mbuju antara lain adalah wali nikah yang dilaksanakan dengan wali tunjuk umumnya dilaksanakan oleh perkawinan yang mana pihak suami masih terikat perkawinan sebelumnya sehingga wali nasab tidak bersedia memberikan perwaliannya kemudian untuk memperoleh pergantian wali dari pengadilan akan membutuhkan waktu panjang dalam kondisi seperti ini nikah dilaksanakanoleh wali tunjuk hanya dapat dilaksanakan oleh perkawinan yang dilaksanakan dibawah tangan.

Berdasarkan uraian diatas dapat disimpulkan bahwa yang menjadi kendala wali nikah dalam pelaksanaannya di Desa Mbuju baik menurut adat serta agama adalah Hidi Paruga(tempat paruga/tenda), dan hakim sangat sedikit sedangkan sebagai besar perkawinan di Desa Mbuju perwaliannya dilaksanakan oleh wali nasab yaitu wali yang ditetapkan atas dasar kedekatan kerabat serta wali nikah yang dilaksanakan dengan wali tunjuk.

\section{Analisis Wali Nikah}

Analisis adalah suatu bentuk penkajian awal yang dilakukan oleh para peneliti sehingga kasus atau masalah yang akan diteliti mudah untuk di pahamidalammengembankan proses penelitian terhadap perwalian dan perkawinan adat.

Data Perkawinan menurut kedudukan wali nikah

\begin{tabular}{|c|c|c|c|c|}
\hline $\begin{array}{l}\mathrm{N} \\
\mathrm{O}\end{array}$ & $\begin{array}{l}\text { Nama } \\
\text { Suami }\end{array}$ & $\begin{array}{l}\text { Nama } \\
\text { Istri }\end{array}$ & $\begin{array}{c}\text { Wali } \\
\text { Nikah }\end{array}$ & $\begin{array}{c}\text { Statu } \\
\text { s } \\
\text { Wali } \\
\text { Nika } \\
\text { h }\end{array}$ \\
\hline $\begin{array}{l}1 \\
2 \\
3 \\
4 \\
5\end{array}$ & $\begin{array}{l}\text { Albap } \\
\text { Iriwan } \\
\text { Yakub } \\
\text { Ahma } \\
\text { d } \\
\text { Safrud } \\
\text { in }\end{array}$ & $\begin{array}{l}\text { Suhart } \\
\text { i } \\
\text { Rahmi } \\
\text { Rohan } \\
\text { a } \\
\text { Juhar } \\
\text { ni }\end{array}$ & $\begin{array}{l}\text { Hakim } \\
\text { Abdul } \\
\text { Ibrahim } \\
\text { H. } \\
\text { Hamdi } \\
\text { H. } \\
\text { isma,il }\end{array}$ & $\begin{array}{l}\text { Wali } \\
\text { Tunj } \\
\text { uk } \\
\text { Wali } \\
\text { Nasa } \\
\text { b } \\
\text { Wali } \\
\text { Nasa } \\
\text { b } \\
\text { Haki } \\
\text { m/ } \\
\text { KUA } \\
\text { Wali } \\
\text { Nasa } \\
\text { b }\end{array}$ \\
\hline
\end{tabular}

Dalam hal ini diadakan analisis terhadap perwalian dan perkawinan adat dari beberapa pasangan suami istri yang melaksanakan perkawinan di Desa Mbuju yang dihadapkan persoalan kesulitan dan adanya wali nikah yang melaksanakan perwaliannya dengan tidak meminta izin kepada kedua orang tua dari mempelai perempuan.

\section{PEMBAHASAN}

a. Sistem Wali Nikah 
Berdasarkan hasil diskripsi data yang dilakukan oleh peneliti tentang sistem perwalian dalam perkawinan adat ini dapat disimpulkan bahwa perwaliandalam perkawinan adat di Desa Mbuju itu adalah secaraIslam dan dikuatkan oleh hukum adat akan tetapi acara tertentu dalam pelaksanaan adat perkawinan itu dilaksanakan secara khas dan dikuatkan oleh masyarakat. Dalam hal wali nikah disini ada proses yang sangat khas dan sangat dikuatkan masyarakat Desa Mbuju tersebut.

Wali nikah dalam melaksanakan perkawinanya dapat secara langsung jika wali nikah ini tidak berhalangan dan dapat juga dilaksanakan dengan berwakil wakil di serahkan kepada orang yang dipandang mampu melaksanakan perwalian dari perkawinan tersebut untuk pelaksanaan perwalian wakil ini tidak dapat diserahkan kepada wakil lagi dengan lain kata wali hanya dapat dilaksanakan sekali yaitu dari wali yang berbeda dalam kedudukannya adalah hakim.

Mengenai sistem wali nikah di Desa Mbuju adalah seperti sistem yang diatur dalam UU. No. 1 Tahun 1974dan sebagaimana syariat Islamdan hukumadat. Sistem tersebut dilihat dari segi kedekatan kerabat dari pihak perempuan yang hendak menikah dan ketika dari kerabat tidak diperoleh maka penggantinya adalah hakim.Hakim menurut hukum adatadalah hakim dalam arti keadaan darurat yang dimaksud hakim dalam keadaan darurat yaitu(wali tunjuk).

Wali tunjuk adalah orang terpilih sebagai pengganti wali nikah ketika wali nikah berdasarkan kerabat baik dapat diperoleh dan perkawinan tersebut tidak memperoleh pergantian wali nikah dari pengadilan (KUA) setempat. Wali hakim dalam keadaan darurat (wali tunjuk) hanya dapat dilaksanakan pada perkawinan dibawah tangan untuk dapat dijadikan hakim dalam keadaan darurat (wali tunjuk) haruslah memenuhi syarat yakni:

1. Beragama Islam

2. Baligh

3. Berakal sehat

4. Merdeka

5. Jujur dan bijaksana

6. Ta'at melaksanakan syariat Islam

7. Laki-laki

8. Dan tidak dalam ihram haji"

\section{b. Kedudukan Wali Nikah}

Berdasarkan beberapa pendapat para responden dalam penelitian ini dinyatakan tidak ada perkawinan yang sah tanpa adanya wali nikah. Hal ini menunjukan bahwa wali nikah dalam perkawinan memiliki kedudukan yang sangat kuat. Adapun kedudukan wali nikah dijelaskan dalam ilmu fiqih Islam untuk dapat melaksanakan perkawinan harus memenuhi syaratsyarat sah dan rukun perkawinan yaitu harus ada calon suami dan istri harus ada minimal dua orang saksi, harus ada wali nikah dan melaksanakan ijab kabul.

Dengan demikian berarti sistem wali nikah dalam perkawianan adat masyarakat DesaMbujumerupakan salah satu dari syarat sah dan rukun perkawinan. Hal ini merupakan suatu kebiasaan yang berlaku ditengah kehidupan masyarakat Desa Mbuju, hal ini terbukti dengan tidak diperolehnya data perkawinan yang dilaksanakan tanpa wali nikah. Masyarakat Desa Mbuju dalam melaksanakan perkawinan selalu dengan adanya wali nikah. Sedangkan sistem wali nikah dalam perkawinan Desa Mbuju adalah merujuk pada aturan undang-undang nomor 1 tahun 1974 hal ini kaitannya dengan fungsi sebagai masyarakat hukum dan merujuk pada ajaran agamaIslamsebagai umat beragama seratus persen masyarakat beragama Islam. Dengan demikian masyarakat Desa Mbujumemandang undang-undang No. 1 tahun 1974 sebagai aturan tertinggi dalam melaksanakan perkawinan dalam kedudukannya sebagai masyarakat hukum. Dan memandang syariat Islam dengan penafsiran yang aktif sebagai penyelesain tertinggi dalam melaksanakan perkawinan dalam fungsi sebagai masyarakat beragama. Dengan demikian berarti masyarakat Desa Mbuju didalam melaksanakan perkawinan toleran dan merujuk kepada undangundang No. 1 tahun 1974 dan syariat Islam.

Tetapi tidak semua perkawinan dapat dilaksanakan sebagaimana diatur dalam UU No. 1 tahun 1974 karena tidak semua perkawinan memenuhi syarat menurut UU tersebut. Perkawinan Desa Mbuju dapat dilaksanakan dengan tidak menurut UU No. 1 tahun 1974 tetapi dilaksanakan dibawah tangan (kawin liar) yaitu perkawinan hanya dengan memenuhi syari'at Islam,hukum adat dan tidak tercatat sebagaimana menurut undang-undang No. 1 tahun 1974. Perkawinan ini tidak dapat dibuktikan secara otentik dan tidak mendapat pengakuan dan perlindungan hukum atau dikatakan tidak memiliki akibat hukum.

Perkawinan yang tercatat dapat dilaksanakan ketika perkawinan itu dapat menunjukan syarat yang lengkap untuk melaksanakan perkawinan sedangkan untuk perkawinan yang tidak dapat menunjukan syarat yang lengkap sebagaimana diatur oleh undang-undang tidak dapat dilaksanakan kalaupun berdasarkan syariat Islam sudah memenuhi syarat untuk melaksanakan perkawinan yang tidak terpenuhi oleh calon suami istri dalam undang-undang untuk melaksanakan perkawinan tercatat Desa Mbuju adalah calon suami istri tidak dapat pengakuan kewarganegaraan secara otentik adanya ikatan perkawinan sebelumnya yang belum diselesaikan dan keberadaan wali nikahnya.

Wali nikah dalam perkawinan adalah merupakan syarat mutlak untuk dapat melaksanakan perkawinan. Undang-undang nomor 1 tahun 1974 mengatur tentang wali nikah yaitu pada pasal 6 ayat (2). Sampai dengan ayat (6). Yaitu tentang syarat-syarat perkawinan yang berbunyi sebagai berikut:

Pasal 6

(2) : Untuk melangsungkan perkawinan seorang yang belum berumur 21 (duapuluh satu) tahun harus mendapat izin kedua orang tua.

(3) : Dalam hal kedua orang tua telah meninggal dunia atau dalam keadaan tidak mampu menyatakan kehendaknya, maka izin dimaksud ayat

(2) pasal ini cukup diperoleh dari orang tua yang masih hidup atau orang tua mampu melaksanakan kehendaknya.

(4) : Dalam hal kedua orang tua telah meninggal dunia atau dalam keadaan tidak mampu untuk menyatakan kehendaknya, maka izin diperoleh dari wali, orang yang memelihara atau keluarga yang mempunyai hubungan darah dalam garis keturunan lurus keatas selama mereka masi hidup dan dalam keadaan dapat melaksanakan kehendaknya 
(5) : Dalam hal ini ada perbedaan pendapat antara orang tua yang disebut dalam ayat (2),(3),(4) pasal ini salah seorang atau lebih diantara mereka tidak menyatakan pendapatnya maka pengadilan dalam daerah hukum tempat tinggal orang yang akan melangsungkan perkawinan atas permintaan orang tersebut dapat memberikan izin setelah terlebih dahulu mendengar orang tersebut dalam ayat (2),(3)dan (4) pasal ini.

(6) : Ketentuan tersebut ayat (1) sampai dengan (5) pasal ini berlaku sepanjang hukum masing-masing agamanya dan agamanya dan kepercayaan itu dari yang bersangkutan tidak menentukan yang lain.

Selanjutnya dalam pasal 14 ayat (1),(2), yaitu mengenai hak dan kewajiban wali terhadap pencegahan perkawinan bunyi serbagai berikut:

(1) Yang dapat mencegah perkawinan ialah para keluarga dalam garis keturunan lurus keatas dan kebawah, saudara wali pengampu dari salah seorang calon mempelai dan pihak-pihak yang berkepentingan.

(2) Mereka yang tersebut pada ayat (1) pasal ini berhak juga mencengah berlangsungnya perkawinan apabila salah seorang dari calon mempelai berada dibawah pengampuan, sehingga dengan perkawinan tersebut nyata-nyata mengakibatkan kesengsaraan bagi calon mempelaiyang lainnya yang mempunyai hubungan dengan orang-orang seperti tersebut dalam ayat (1).

Menurut Islamnikah merupakan unsur dalam perkawinan dan sangat menentukan akad perkawinan itu sah atau tidak sah. Dan bahkan dijelaskan bahwa tidak ada perkawinan yang sah tanpa ada wali nikah. Adapun yang dapat dijelaskan wali nikah dalam perkawinan adalah orang Islam, baligh berakal sehat, laki-laki dan bersikap adil yang dilaksanakan oleh keluarga terdekat dan orang atau pihak lain yang diatur menurut hukum adat.

Di dalam melaksanakan perkawinan wali nikah dalam kedudukannya tidak selalu ada dan atau memiliki kesempatan untuk melaksanakan perwaliannya. Hal ini dapat disebabkan karena kematian, penyakit atau berpergian dan atau tidak terpenuhinya syarat-syarat tertentu untuk menjadi wali nikah sehingga dalam melaksanakan perwalian seseorang tidak memiliki kesempatan. Dalam hal ini untuk melaksanakan perkawinan wali nikah dapat dilaksanakan oleh wali nikah tingkat berikutnya sepanjang wali dalam urutan berikutnya itu memenuhi syarat. Wali nikah setelah bapak, kakek dan seterusnya adalah saudara kandung. Saudara kandung dapat dilaksanakan perwaliannya bila bapak, kakek dan seterusnya tidak ada atau ada tetapi jauh dan tidak mau atau enggan memberikan perwaliannya. Dan wali nikah selanjutnyan adalah saudara sebapak, wali pada tingkatan ini dapat bertindak sebagai wali nikah setelah saudara kandung tidak ada atau enggan memberikan perwaliannya dan begitu seterusnya sehingga tingkat urutan terakhir. Kemudian jika ada wali dalam tingkatan yang sama maka salah satunya dapat melaksanakan perwaliannya dengan izin perempuan yang hendak kawin tersebut kalaupun tanpa ada persetujuan wali yang lainnya. Bila wali nikah dalam tingkatannya adalah calon suami maka yang berhak menjadi wali nikah pada perkawinan itu adalah wali nikah pada tingkatan berikutnya. Kalaupun wali nikah terdekat dengan anak perempuan itu bertempat tinggal jauh dari tempat tinggal perempuan yang hendak melaksanakan perkawinan ditempat itu dan ada wali maka yang menjadi wali nikah pada perkawinan itu adalah hakim bukan wali nikah pada tingkatan berikutnya karena wali nikah pada tingkatannya dan tetapi ada kesulitan memberikan perwaliannya. Dalam melaksanakan perwaliannya seseorang harus meminta izin terlebih dahulu kepada perempuan yang hendak dikawinkannya, hal ini berlaku pada semua tingkatan wali nikah kecuali wali nikah mujbir.

Mengenai izin ini berlaku juga kepada wali hakim yaitu wali nikah hanya dapat melaksanakan perkawinan atas seizin perempuan yang berhendak menikah tersebut dan izin dari perempuan itu sah bila perempuan itu telah berumur baligh.

\section{c. Kendala yang dihadapi wali nikah dalam perkawinan Adat}

Di dalam perkawinan adat sering kali dihadapkan dengan kendala- kendala yang bisa menunda bahkan membatalkan perkwinan itu seperti tidak adanya seorang wali.Perkawinan yang di hadapkan kesulitan wali nikah, perkawinan ini sudah jelas tidak dapat dilaksanakan sebagaimana perkawinan biasanya, dalam artian perkawinan ini tidak dapat dilaksanakan karena wali nikah tidak ada.sebagaimana sistem wali nikah menurut UU No.1 1974,agama Islam maupun menurut adat di Desa Mbuju maka perkawinan ini akan dilaksanakan dengan wali hakim adapun untuk mendapatkan pergantian wali sebagaimana yang diatur menurut UUP wali hakim itu akan di kabulkan jika memenuhisyarat-syarat tertentu baik syaratsyaratsebagaimana syariat Islam maupun syarat adminitarasi. Wali nikah menurut UndangUndang No. 1 Tahun 1974

Wali nikah menurut UU No thn 1974 adalah orang yang melakukan akad nikah mewakili pihak mempelai wanita, karena wali merupakan syarat sah nikah, danakad nikah yang dilakukan tanpa wali dinyatakan tidak sah.

Dalam undang-undang perkawinan (UU No.1 Tahun 1974) telah dicamtumkan suatu azas bahwa tujuan perkawinan adalah untuk membentuk keluarga yang kekal, bahagia, dan sejahtera. Sehingga secepat mungkin supaya perkawinan itu tidak dipersulit dan seballiknya mempersulit jalannya perceraian. Adapun undang-undang No.1 tahun 1974 tentang perkawinan itu merupakan peraturan yang diberlakukan secara nasional di Indonesia dengan demikian maka masyarakat Desa Mbuju sebagai bagian dari bangsaIndonesia tentunya didalamnya melaksanakan perkawinan diatur oleh undang-undang perkawinan tersebut.

Mengenai perkawinan ini dijelaskan dalam fiqih Islam dan syari'at Islam dengan jelas rinci, hal tersebut tentu untuk kepentingan umat Islamdidalam melaksanakan perkawinan secara menyeluruh termasuk juga umat Islam yang ada di Desa Mbuju. Dengan demikian masyarakat Desa Mbuju juga merujuk terhadap ajaran Islam didalam melaksanakan perkawinan.

Selanjutnyaperkawinan menurut adat diDesa Mbuju khususnya mengenai hukum, syarat dan rukunnya selalu merujuk pada undang-undang No.1Tahun 1974 dan ajaran Islam. Undang-undang No. 1 tahun 1974 merupakan rujukan masyarakat untuk 
mendapat pengakuan dan lindungan hukum mengenai perkawinannya.

Sedangkan syariat agama Islamadalah rujukan masyarakat dalam melaksanakan perkawinan baik untuk kepentingan pengakuan dan perlindungan hukum maupun perkawinan yang dilaksanakan dibawah tangan (tanpa pengakuan dan perlindungan hukum). Dengan demikian berarti perkawinan yang dilaksanakan menurut (UU No. 1 Tahun 1974) merupakan aturan perkawinan yang memenuhi syarat Islam dan sebaliknya tidak semua perkawinan menurut syariat Islam memenuhi syarat sebagaimana UU No. 1tahun 1974.

Selanjutnya adat perkawinan di Desa Mbuju merujuk kepada peraturan (UU No. 1 tahun 1974) sebagai aturan perkawinan dalam hal ini kaitannya dengan kepentingan peraturan sebagai masyarakat dan merujuk pada syariat Islam kaitannya dengan kepentingan agamanya dan dilaksanakan berdasarkan norma-norma lain dilingkungannya.

Jadi hubungan antara Undang-undang No. 1 tahun 1974, syari'at Islam dan adat dalam kehidupan masyarakat Desa Mbuju terhadap pelaksanaan perkawinan merupakan suatu aturan sebagai rujukan masyarakat dalam kepentingan melaksanakan perkawinan. Perkawinan menurut undang-undang No1 tahun 1974 merupakan perkawinan yang memenuhi syarat sebagaimana syariat Islamdan adat. Dan tidak semua perkawinan menurut agama dan adat di Desa Mbuju memenuhi syarat untuk perkawinan tercatat. Dengan demikian berartiperkawinan bisa saja terjadi tanpa memenuhi syarat sebagaimana diatur dalam UU No . 1 tahun 1974 tetapi mutlak perkawinan tersebut memenuhi syariat Islam dan diterima atau mendapat pengakuan masyarakat sebagai pasangan suami istri. Jadi dengan demikian dapat dikatakan bahwa bentukbentuk perkawinan di Desa Mbuju yaitu:

1) Perkawinan menurut UU NO. 1 tahun 1974, yang disebut dengan perkawinan yang resmi dan mendapat pengakuan hukum, pengakuan agama dan pengakuan adat yang kemudian mendapat perlindungan hukum, agama dan adat. Perkawinan ini dapat dibuktikan secara otentik berupa Akte Nikah.

2) Menurut ajaran Islamdijelaskan bahwa perkawinan bertujuan untuk dapat memelihara diri dari perbuatan zina yang merupakan perbuatan yang sangat dilaknat oleh Allah SWT. Lebih dari itu perkawinan juga bertujuan sebagai bentuk ibadah yang merupakan sunah nabi saw.Menyelesaikan masalah ketika dalam rumah tangga keluarga yang melaksanakan perkawinan liar ini adalah penyelesaian atas dasar sepakat kedua pihak dan bila sepakat tidak dapat dicapai maka upaya menyelesaikan dapat diteruskan hingga pemerintah desa. Bentuk perkawinan ini jarang dilakukan masyarakat tetapi dilakukan dalam keadaan terpaksa atau sebagai penyelesaian dalam keadaan darurat haltersebut tentu untuk kepentingan umat Islam didalam melaksanakan perkawinan secara menyeluruh termasuk juga umat Islam yang ada di Desa Mbuju dengan demikian masyarakat Desa Mbuju juga merujuk terhadap ajaran Islam didalam melaksanakan perkawinan baik untuk kepentingan pengankuan dan perlindungan hukum maupun perkawinan yang dilaksanakan dibawah tangan (tanpa pengakuan dan perlindungan hukum).

3) Perkawinan menurut adat diDesa Mbuju merupakan perkawinan yang melandasi, menurut hukum adat dan menurut syariat Islam karena kedua bentuk perkawinan itu dapat diterima dalam kehidupan masyarakat Desa Mbuju, dalam arti dengan perkawinan itu masyarakat dapat mengakui bahwa yang melaksanakan perkawinan bukan resmi atau liar (dibawah tangan) itu sebagai pasangan suami istri dan mereka dapat hidup tenang dalam rumah tangga. Perkawinan yang tidak diterima masyarakat merupakan perkawinan yang diragukan hubungan sebagai suami istri dan bisa mendapat teguran dari aparat pemerintah kadus sehingga berkali-kali dan bila teguran tersebut tidak direspon maka masyarakat bertindak dengan tindakanyang lebih keras berupa pengusiran dan penyerangan.

\section{SIMPULAN DAN SARAN}

\section{KESIMPULAN}

Berdasarkan hasil penelitian dan pembahasan diatas maka dapat ditarik kesimpulan, bahwa :

a. Sistem perwalian dalam perkawinan adat di Desa Mbuju dilaksanakan berdasarkan pengakuan masyararkat dengan merujuk pada undang-undang perkawinan.,(UU No. 1 Tahun 1974). Perkawinan adalah ikatan lahir batin antara seorang pria dengan seorang wanita sebagai suami istridengan tujuan membentuk keluarga atau rumah tangga yang bahagia dan kekal berdasarkan ketuhanan yang maha esa secara agama dan adat kebiasaan sebagai perkawinan yang sah.

b. Kendala-kendala yang dihadapi wali nikah dalam pelaksanaan perkawinan adat di Desa Mbujubaik menurut adat serta agama adalah Hidi paruga (tempat paruga/tenda), dan hakim sangat sedikit sedangkan perwaliannya dilaksanakan oleh wali nasab yaitu wali yang ditetapkan atas dasar kedekatan kerabat serta wali nikah yang dilaksanakan dengan wali tunjuk.

\section{SARAN-SARAN}

Untuk memperoleh pengakuan dan perlindungan hukumdalam melaksanakan perkawinan maka disarankan kepada segenap pihak agar secepat mungkin perkawinanya dilaksanakan dengan pencatatan menurut UU No. 1 tahun 1974, kalaupun adat memberi peluang adanya perkawinan dibawah tangan.

\section{DAFTAR RUJUKAN}

Arikunto,Suharsimi.2006.MetodelogiPenelitianTeoridanPrakt ek.Bandung: Rineka Putra.

Arikunto, Suharsimi, 2004. Prosedur Penelitian. Jakarta: Bina Aksara.

Arifin, Zainal, 2006. Metodelogi Penelitian.Jakarta: PT Gramedia.

Artayasa,I Nyoman, 2004.PetunjukTeknisPerkawinan Hindu. Surabaya.

Ahmad Juntak, 2006.PengantarHukumPerkawinan. Jakarta: PT Grafindo.

Anonim 2010. Undang-undangRepublikIndonesiaNo. 1Tahun1974TentangPerkawinan.Jakarta. 
B. Matthew Milles,Michael, Huberman, 1992. Analisis Data Kualitatif. Jakarta: UI Press.

Depag, RI 1991/1991; 49

Departemen Agama RI,2001,dalam Maknah 2004;44.

Furchon, Arif, 2006. MetodelogiPenelitianKualitatif. Jakarta: BulanBintang.

Haar, BznTer, 2006.Asas-asasdanSusunanHukumAdat (TerjemahanSoebaktiPoesponoto Ng.)PradnyaParamita:Jakarta

Hadikusuma,Hilman.2009.PengantarIlmuHukumAdatIndone sia.Bandung:MandarMaju

Http:/blosgpot .com /2009/03/pandangan -Islam terhadapperwalian.html

Maknah,2004.Studi Analisis Tentang Sistim Perwalian dalam Perkawinan Adat di Desa Kawo Kecamatan Pujut Kabupaten Lombok Tengah. Mataram:Jurusan Pendidikan Ilmu Pengetahuan Sosial Fakultas Keguruan Dan Ilmu Pendidikan UnisversitasMuhammadyah Mataram.

Ramulyono, Mohd, Idris2007. Hukum Perkawinan dan Kompilasi Hukum:Jakarta Bumi Aksara.

Miles, M.B. Hubberman, A. M. 1992. Analis Data Kualitatif. Jakarta : UI Pres

Mulyana, 2001. MetodelogiPenelitianKualitatif. Surabaya: Usaha Nasional.

H. Hamdi Wasyi, Pemuka Agama ;(2012)

Wire dahat interview, tangal 12/11;Febuari/2012.

Ryanto,Yatim, 2001. MetodelogiPenelitians. Jakarta: PT Raja Grhafindo.

Suharsimin 2001/200o,Metodelogi Penelitian Kualitatif:Surabaya Usaha Nasional.

Soekanto,Soerjono.2007. Metodelogi Penelitian Kualitatif. Jakarta:PT Grafindo.

Surakhmad Winarno,2004.Pengantar Penelitian Ilmiah. Jakarta: Gahlian Indonesia.

Sugiyono, 2005. Metode Penelitian Kuliatitatif. Bandung: PT AlfaBeta.

Soekanto, 1985.Meninjau Hukum Adat di Indonesia.Jakarta: PT Rajawali. 